\title{
Enteric Pathogen Bacteria in Non-Broiler Chicken Egg Shells from Traditional Market and Supermarket, Jatinangor Subdistrict, West Java
}

\author{
Kavita Arumugam, ${ }^{1}$ Sunarjati Sudigdoadi, ${ }^{2}$ Gaga Irawan Nurgraha ${ }^{3}$ \\ ${ }^{1}$ Faculty of Medicine Universitas Padjadjaran, ${ }^{2}$ Department of Microbiology and Parasitology \\ Faculty of Medicine Universitas Padjadjaran, ${ }^{3}$ Department of Medical Nutrition, Faculty of \\ Medicine Universitas Padjadjaran
}

\begin{abstract}
Background: Around 1.5 million of children dying annually due to diarrhea. Contaminated food is one of the sources of the diarrhea incidence (food borne diseases). Eggs are one of the least expensive forms of protein which is affordable by the community and is easily to find in either traditional or modern market/ supermarkets. The objective of this study was to identify enteropathogenic bacteria contamination on nonbroiler (ayam kampung) egg shell and to compare the findings between eggs sold in traditional and modern markets.

Methods: This was a descriptive study performed at the Microbiology Laboratory of the Faculty of Medicine, Universitas Padjadjaran. A total of 40 eggs were used, 20 from two traditional markets and 20 from two modern markets. The eggs were swabbed using saline, dipped in tryptic soy broth and streaked on Mac Conkey agar. The collected data were analyzed and presented in tables.

Results: Out of 40 samples, there were 19 positive cultures found from the traditional market and 16 from the modern market. There were 30 pink colonies indicating that they were lactose fermented, 5 transparent colonies indicated non-lactose fermentation, 4 showed no colony growth, and 1 grew an unidentified colony. The most found bacteria were Klebsiella sp. and Enterobacter sp. in both market.

Conclusions: Eggs shells from traditional and modern markets are contaminated with Enteropathogenic microbes. [AMJ.2015;2(3):414-17]
\end{abstract}

Keywords: Enterobacter sp., Klebsiella sp., non-broiler (ayam kampung) eggs

\section{Introduction}

Since a decade ago, there has been an increased rate of food illness being registered by Asian countries. Around 1.5 million of children were dying annually due to diarrhea. Food can be contaminated due to several factors, bacteria, followed by virus, parasites and toxins. According to World Health Organization (WHO) data, over the 10 years, $75 \%$ of infectious diseases are caused by bacteria and other pathogens. ${ }^{1}$

Food can be contaminated from farm to table, for instance, contaminated meat with fecal matter due to improper handling, inadequate food preparing, inappropriate personal hygiene and poor hygiene in the surrounding. Any of this these factors can lead to food contamination and resulting in foodborne diseases to consumers.

Food-borne diseases that carry microorganisms, examples such as bacteria and viruses or toxins. The common symptoms of food-borne diseases are diarrhea, vomiting, cramps and nausea. ${ }^{2}$

The most common symptom of food-borne disease is diarrhea caused by enteropathogenic bacteria. The examples of these bacteria are Eschericia coli, Salmonella sp,. and Shigella sp. and others. ${ }^{3}$ Enteropathogenic Eschericia coli is the main cause of diarrhea in infants these especially in developing countries. Each year, around 105 million of Shigella cases are reported worldwide. ${ }^{4}$ Moreover, it is the most common cause of bloody diarrhea. More than 1 million cases of Salmonella are being reported and their infections are more common in

Correspondence: Kavita Arumugam, Faculty of Medicine, Universitas Padjadjaran, Jalan Raya Bandung-Sumedang Km.21, Jatinangor, Sumedang, Indonesia, Phone: +628170206265 Email: nita_kav@yahoo.com 
Kavita Arumugam, Sunarjati Sudigdoadi, Gaga Irawan Nurgraha: Enteric Pathogen Bacteria in Non-Broiler415 Chicken Egg Shells from Traditional Market and Supermarket, Jatinangor Subdistrict, West Java

young children and elder people. ${ }^{4}$

E.coli, Salmonella sp., and Shigella sp. are chosen as the bacteria in this study, according to a surveillance study, 'Surveillance of bacterial pathogens of diarrhea disease in Indonesia' which was conducted in 2 years on 6.760 people. Among 587 diarrhea patients who are positive for bacterial infection, $39 \%$ of them are affected by Shigella and $26 \%$ are by Salmonella. ${ }^{5}$ Another study, 'Enterotoxigenic Escherichia coli and other causes of infectious pediatric diarrheas in Jakarta, Indonesia, conducted a stool survey among children, and discovered that E.coli is the second most frequent cause of diarrhea with highest prevalence $(17.9 \%)$ among infants. ${ }^{6}$

The reason why eggs were chosen in this study is because eggs are one of the least expensive forms of protein, which is affordable to everyone. The American Heart Association stated that an egg a day for a normal healthy adult is good. ${ }^{7}$

The contamination of these eggs can occur in a stage starting from the host itself (chicken) until it reaches consumers, especially nonbroiler chicken eggs. There are two types of breeding system, one is battery cage and another one is free range or aviaries. According to the Centre of Food Safety of Hong Kong, egg contamination can occur via two different ways: vertical transmission through the ovary transmission and horizontal transmission. ${ }^{8}$ Vertical transmission occurs when bacteria are transmitted from infected reproductive tissues to eggs during the shell formation and is mostly associated with pathogenic bacteria ${ }^{8}$, whereas horizontal transmission occurs when fecal contamination stained on the egg shell as when eggs are released via the cloaca. Contaminations through environmental vectors such as pesticides, farmers are also categorized as horizontal transmission. At this point, numerous bacteria may gain entry through pores or cracks on shell of eggs. Eggs with cracks on the shell allow the entry of bacteria into the egg content. In addition, bacteria may contaminate egg contents at breaking for cooking purpose when it is not being washed before cooking. ${ }^{8}$

The objective of this study was to identify enteropathogenic bacteria contamination on non-broiler (ayam kampung) egg shell and to compare the findings between eggs sold in traditional and modern markets.

The results of this study serve as knowledge and can be used as a guide on preventive measures to be taken. This study will also help us to foresee if there is a need for a future study.

\section{Methods}

This study was conducted at the Microbiology Laboratory in Faculty of Medicine Universitas Padjadjaran. Samples were collected from four sources; two traditional markets and two supermarkets in Jatinangor. A total number of 40 samples were taken from the four sources with ten non-broiler chicken eggs samples from each source. The number of samples that will be used in this study was determined using the 'Rule of Thumb' where the total sample size should be more than 30 . Nonbroiler chicken eggs that had cracked shell were excluded from this study.

The eggs were swabbed using cotton swabs, dipped in physiologic saline, and then the cotton swabs were dipped in tryptic soy broth for 24 hours and incubated at $37^{\circ} \mathrm{C}$. The solutions were then cultured on Mac Conkey agar and incubated at $37^{\circ} \mathrm{C}$ in the incubator for 24 hours.

Afterward colonies that grew on the agars were analyzed. The lactose fermenter and non-lactose fermenters were observed. Gram staining was carried out in order to differentiate gram-positive and gram-negative. Only the gram negative bacteria underwent the biochemistry test such as kligler iron agar (KIA), motility, indole and urease (MIU) agar and citrate agar. Hereafter, the results were analyzed.

\section{Results}

Out of 40 samples, 19 positive growths were found on Mac Conkey agar from a traditional market and 16 positive growths found from a supermarket.

During observation on Mac Conkey agar plate, from the total sample of 40, 30 pink

\section{Table 1 Percentage of Bacteria Found on Non-Broiler Chicken Egg Shells from Traditional Market}

\begin{tabular}{lc}
\hline \multicolumn{1}{c}{ Bacteria } & $\begin{array}{c}\text { Number of Non- } \\
\text { Broiler Chicken Eggs }\end{array}$ \\
\hline Escherichia coli & 1 \\
Enterobacter sp. & 9 \\
Klebsiella sp. & 7 \\
Citrobacter sp. & 2 \\
Gram positive bacillus & 1 \\
\hline
\end{tabular}




\begin{tabular}{lc}
$\begin{array}{c}\text { Table } 2 \text { Percentage of Bacteria Found on } \\
\text { Non-Broiler Chicken Egg Shells from } \\
\text { Supermarket }\end{array}$ \\
\hline \multicolumn{1}{c}{ Bacteria } & $\begin{array}{c}\text { Number of Non- } \\
\text { Broiler Chicken Eggs }\end{array}$ \\
\hline Shigella sp. & 2 \\
Enterobacter sp. & 4 \\
Hafiniaalvei & 3 \\
Klebsiella sp. & 7 \\
No growth & 4 \\
\hline
\end{tabular}

colonies were indicated lactose fermented, five transparent colonies were indicated non lactose fermented, four were with no colony growth, and 1 colony was found unidentified.

\section{Discussion}

Based on the results found, it was clearly proven that non-broiler chicken eggs shell contained several types of Enterobacteriaceac. Compared to previous study by Wall et al. ${ }^{9}$, Enterobacteriaceac was found in higher proportion on egg shells which supported this experiment results.

E.coli a normal flora of intestine that can become pathogenic when it reaches outer tissues of its usual site is the most common bacteria that can cause diarrhea. The study which supports this experiment result is from 'Bacterial Contamination On Egg Shells' where the researcher analyzed eggs from few sources and the highest range of bacteria found was E.coli. ${ }^{10}$ Although in this study, E.coli was found only $5.00 \%$, it needs to take precaution.

Salmonella sp., a member of Enterobacteriaceac family can cause enteric fever, diarrhea and systemic infection. However, there were no Salmonella found from any of the samples, either traditional market or supermarket. According to scientist, it was estimated that on an average 1 of every 20,000 eggs might contain Salmonella. ${ }^{2}$

Based on this study, there was $10.00 \%$ of Shigella found on chicken egg shells. Although the percentage is small, serious precaution should be taken. The pathogenic bacteria, Shigella, can cause bacillary dysentery. They are extremely communicable as the infective dose is around 103 organisms only.

There were other Enterobacteriaceac found in this experiment also. This can be due to their characteristics as a normal pathogen in intestinal tract of animals, so as in this study, it can be found in chicken or in the water sources, soil, sewage or using eggs handling method, by which lead to the contamination of egg shells.

According to the results from Musgrove and Papadoude, they concluded that most frequently isolated gram negative bacteria from eggs are Enterobacter sp.,E.coli, and Klebsiella sp. ${ }^{11}$ Apart from E.coli and Shigella sp., most abundant Enterobacteriaceac found in this study was Enterobacter sp., followed by Klebsiella sp., Hafniaalvei and Citrobacter sp. Under previous analysis of types of bacteria found on eggs depending on their source, out of 184 samples, Klebsiella sp and Enterobacter sp. were found in 17 and 23 eggs, respectively. ${ }^{11}$

The most frequent Enterobacter sp. found in traditional market eggs and supermarket eggs stood a total of $45 \%$ and $20 \%$, respectively. Enterobacter sp. is a nosocomial pathogenic bacterium which usually causes infection of urinary and respiratory tract.

Klebsiella sp. was found in quite a high percentage in this study, $35.00 \%$ from the traditional market and the supermarket respectively. This rod shaped, gram negative are pathogenic bacteria is involved in causing nosocomial infection, pneumonia and urinary tract infection.

Hafniaalvei was found $15.00 \%$ in supermarket eggs. These gram negative bacteria are rarely isolated from specimens. These bacteria can cause nosocomial infection. Apart from Enterobacteriaceac, there was $5.00 \%$ of gram positive bacillus found from the samples collected from the traditional market. Presence of these bacteria can be due to contamination from the environments during the streaking procedure on Mac Conkey.

There was also $20.00 \%$ of no colony growth found on agar, this can be due to no bacteria found on egg shells, or maybe there were bacteria which required other media to be cultured as in this experiment. Only Mac Conkey agar was used.

Previously, Haribudiman ${ }^{12}$ found three E.coli and one Staphyloccus out of 30 samples.

In conclusion, the comparison between traditional market and supermarket was chosen as part of this study. The difference between these two sources is the chicken breeding system. Eggs sold in supermarket are from battery cage system and eggs sold in traditional market are free-range poultry or aviaries. There were no significant differences found in samples from those sources in this study. Eggs from both places were equally contaminated.

References 
1. WHO. Diarrhoeal disease.Geneva: WHO. 2009 [Cited 2012 May 1];Available from: http://www.who.int/mediacentre/ factsheets/fs330/en/index.html.

2. American Egg Board. Incredible egg. Illinois, America: American Egg Board; 2012 [Cited 2012 May 4]; Available from: http://www.incredibleegg.org/egg-facts/ egg-safety/eggs-and-food-safety.

3. Brooks GF, Carroll KC, Butel JS, Morse SA, editors. Medical microbiology. 24th ed. New York,US: The McGram- Hill Company; 2004.

4. Kumar V, Abbas A, Fausto N. Pathologic basic of disease. 8th ed. Philapedia: Saunders Elsevier; 2010.

5. Oyofo BA, Lesmana M, Subekti D, Tjaniadi P, Larasati W, Putri M SC, et al. Surveillance of bacterial pathogens of diarrhea disease in Indonesia. Diagn Microbiol Infect Dis.2002;44(3):227-34

6. Subekti D, Lesmana M, Komalarini S, Tjaniadi P, Burr D, Pazzaglia G. Enterotoxigenic Escherichia coli and other causes of infectious pediatric diarrheas in Jakarta, Indonesia. Southeast Asian J Trop Med Public Health. 1993;24(3):420-4

7. Kurzrock D. Ask the expert. Sacramento,
California [Cited 2012 September 14]; Available from: https://www.mylifestages. org/asktheexpert/QuestionAnswer. page?questionid=256.

8. Chong K. Bacteria on eggs-should eggs be washed. Hong Kong: Centre for Food Safety; 2008 [Cited 2012 June 25]; Available from: http://www.cfs.gov.hk/ english/multimedia/multimedia_pub/ multimedia_pub_fsf_29_01.html.

9. Wall H, Tauson R, Sorgjerd S. Bacterial contamination of eggshells in furnished and conventional cages. J Appl Poult Res (Spring). 2008 17(1):11-6

10. World Poultry. Bacterial contamination on egg shells. 2012 ; [Cited 2012 November 11]. Available from: http://www. worldpoultry.net/Broilers / Markets-Trade/2012/5/Bacterial-contaminationon-egg-shells-WP010384W/

11. Pysniak S. Occurence of gram-negative bacteria in hen's eggs depending on their source. Pol J Vet Sci. 2010;13(3):507-13.

12. Haribudiman 0 . Isolasi and identifikasi bakteri penyebab diare pada telur puyuh yang dijual di beberapa pasar di Kelurahan Sukajadi [Minor thesis]. Bandung: Universitas Padjadjaran; 2003. 